\title{
EFFECT OF BUTANOLIC FRACTION OF Desmodium adscendens ON THE ANOCOCCYGEUS OF THE RAT
}

\author{
BARRETO, G. S. \\ Department of Basic Health Sciences, Universidade Federal de Mato Grosso, \\ Av. Fernando Corrêa Costa, s/n, CEP 78060-900, Coxipó, Cuiabá, MT, Brazil \\ Correspondence to: Genesson dos Santos Barreto, Universidade Federal de Mato Grosso, \\ Av. Fernando Corrêa Costa, s/n, CEP 78060-900, Coxipó, Cuiabá, MT, Brazil, e-mail: genesson@cpd.ufmt.br \\ Received September 20, 2000 - Accepted April 3, 2001 - Distributed May 31, 2002
}

(With 4 figures)

\begin{abstract}
The chemical composition of plants can vary according to factors such as soil and time of collection. Desmodium adscendens (Sw.) D.C. var. adscendens (Papillionaceae) is a plant employed in the treatment of asthma in Ghana, Africa. Studies have shown that butanolic extract inhibits contraction of the ileum and trachea in guinea pigs. In Mato Grosso, this plant is used only in the treatment of ovarian inflammation. The objective of this work was to verify if the plant found in Mato Grosso also relaxes smooth muscle and to understand better its action. The cumulative application of the butanolic fraction relaxed the contraction maintained in the isolated anococcygeus of a rat, induced by high potassium, but not that induced by phenylephrine. Relaxation was not altered by methylene blue. The butanolic fraction reduced in a concentration-dependent way the maximum response of concentration-response curve to calcium in the anococcygeus muscle. The results suggest that the butanolic fraction acts, at least partly, through the blockade of voltage-sensitive $\mathrm{Ca}^{+2}$ channels.
\end{abstract}

Key words: smooth muscle, anococcygeus, Desmodium adscencens, relaxation.

\section{RESUMO}

\section{Efeito da fração butanólica de Desmodium adscendens no anococcígeo de rato}

A composição química das plantas pode variar em função de fatores como solo e época da coleta. Desmodium adscendens (Sw.) D.C. variedade adscendens (Papillionaceae) é uma planta empregada no tratamento da asma em Gana, África. Estudos indicam que o extrato butanólico inibe as contrações do íleo e traquéia de cobaio. Em Mato Grosso, essa planta é utilizada somente no tratamento de inflamação ovariana. O objetivo do trabalho foi verificar se fração butanólica da planta encontrada em Mato Grosso relaxa o músculo liso e compreender melhor seu mecanismo de ação. A aplicação acumulativa da fração butanólica relaxou a contração mantida do anococcígeo de rato induzida por potássio alto, mas não a induzida pela fenilefrina. O relaxamento não foi alterado pelo azul de metileno. Além disso, reduziu a resposta máxima da curva concentração-resposta ao cálcio. Os resultados sugerem que a fração butanólica atua, pelo menos em parte, por intermédio do bloqueio de canais de $\mathrm{Ca}^{+2}$ voltagem dependente.

Palavras-chave: músculo liso, anococcígeo, Desmodium adscendens, relaxamento.

\section{INTRODUCTION}

The degree of contraction of cells of smooth muscle determines the lumen in blood vessels and airways as well as the propulsive function of the gastrointestinal and genitourinary tract. Abnormalities in the contraction are related to a variety of clinical conditions including hypertension and asthma. Substances that act in contractility control of smooth muscle are useful in the treatment of 
disorders due to contraction abnormalities in such muscle.

Desmodium adscendens (Sw.) D.C. var. adscendens (Papillionaceae) is used in the treatment of asthma in Ghana, Africa (Ampofo, 1977); it inhibits contraction of the guinea pig's ileum and airways (Addy \& Awumey, 1984; Addy \& Burka, 1988; Addy, 1989).

In Brazil, it is easily found in the Northeast, Center West, and Southeaste regions (Pio Corrêa, 1984).

In Mato Grosso, the plant is used only in the treatment of ovary inflammation (Guarin Neto, 1996). There it is known as "amores do campo" or "carrapichinho", and in São Paulo and Rio Grande do Sul as "pega-pega".

It has been suggested that the action mechanism of the plant is due to the depletion of the histamine stocks (Addy \& Awumey, 1984); the inhibition of the cicloxigenase and lipoxigenase enzymes (Addy \& Burka, 1988); the increase of the prostaglandin synthesis, $\mathrm{PGE}_{2}$ and $\mathrm{PGF}_{2 \mathrm{a}}$; the opening of the $\mathrm{BK}_{\mathrm{Ca}}$ channels (MacManus et al., 1993), or the inhibition of cytochrome P450 NADPH-dependent arachidonic acid metabolism (Addy \& Schartzman, 1992).

As the chemical composition of the plant varies according to factors such as collection time or soil and as the action of the plant is not very clear yet, the objective of this study was to determine whether the butanolic fraction of the aqueous extract of Desmodium adscendens found in Cuiabá, Mato Grosso, relaxes smooth muscle and to understand better its action, by comparing its effects with that of an inhibitor of the soluble guanylyl cyclase (sodium nitroprusside), an activator of the adenylato cyclase (forskolin), and blocker of $\mathrm{Ca}^{+2}$ channels voltage dependent (nifedipine) and opener of $\mathrm{K}^{+}$channels (cromakalin).

\section{MATERIALS AND METHODS}

\section{Collection and identification of the botanical material}

The Desmodium adscendens was collected at the campus of the Federal University of Mato Grosso (UFMT), Cuiabá, Mato Grosso.

Taxonomic confirmation was accomplished by Prof. Dr. Germano Guarin Neto of the Botany and Ecology Dept., Biology Institute/UFMT. A voucher specimen (n. 10930) was deposited in the Central Herbarium of UFMT.

Obtainment of the crude aqueous extract and butanolic fraction of the aqueous extract of Desmodium adscendens

Dried and ground leaves of Desmodium adscendens were extracted for 48 hours with water in a Soxhlet apparatus; the extract was concentrated in a rotary evaporator and freeze-dried.

The aqueous solutions of the freeze-dried material were extracted thrice, each time with 3 volumes of water-saturated n-butanol, and the nbutanol extracts were pooled and concentrated in a rotary evaporator to form a brownish syrup; this was freeze-dried (MacManus et al., 1993).

On one occasion, the freeze-dried n-butanol fraction was dissolved in distilled water.

\section{Preparation of the anococcygeus muscle}

Male Wistar rats (200-220 g) were sacrificed and the anococcygeus muscle removal performed through an incision in the anus, exposing the distal portion of the rectum.

Isotonic contractions were registered by a quimograph, under a resting load of 1 gram.

The organs were suspended in a bath of isolated organ $(10 \mathrm{ml})$ containing Tyrode solution (mM): $\mathrm{NaCl} 136.9, \mathrm{KCl} 2.68, \mathrm{CaCl}_{2}$ 1.8, $\mathrm{MgCl}_{1}$, $\mathrm{NaHCO}_{3}$ 11.9, and glucose 5.5.

They were allowed to equilibrate for $60 \mathrm{mi}-$ nutes, at a temperature of $37^{\circ} \mathrm{C}$ and under continuous aeration with Tyrode solution changed every 15 minutes. Tyrode solution diphenydramine (1 mM) was also added.

Effects of EBDA, cromacalin, forskolin, nifedipine, and sodium nitroprusside on the maintained contraction evoked by phenylephrine and $80 \mathrm{mM} \mathrm{K} \mathrm{K}^{+}$

After equilibration, the preparations were contracted with phenylephrine $\left(10^{-5} \mathrm{M}\right)$ or $80 \mathrm{mM}$ potassium. After the contraction had stablized, tissues were exposed to cumulative concentrations of EBDA (0.01-3 mg/ml), cromakalin $\left(10^{-6}-10^{-5}\right.$ $\mathrm{M})$, forskolin $\left(10^{-7}-3 \times 10^{-5} \mathrm{M}\right)$, nifedipine $\left(10^{-8}\right.$ $\left.10^{-3} \mathrm{M}\right)$, and sodium nitroprusside $\left(3 \times 10^{-8}\right.$ $\left.10^{-4} \mathrm{M}\right)$.

The relaxant response to each concentration was allowed to reach a stable level before the next addition was made. 
Effect of methylene blue on the relaxation produced by $E B D A$ and sodium nitroprusside on the maintained contraction evoked by phenylephrine and $80 \mathrm{mM} \mathrm{K}^{+}$

Cumulative concentrations of EBDA (0.1-3 $\mathrm{mg} / \mathrm{ml})$ and sodium nitroprusside $\left(3 \times 10^{-8}-10^{-4} \mathrm{M}\right)$ were added in the absence or presence of methylene blue $\left(10^{-3} \mathrm{M}\right)$, pre-incubated, for $20-30$ minutes.

Effect of EBDA on the concentration-response curve to the calcium evoked by $80 \mathrm{mM} \mathrm{K} \mathrm{K}^{+}$

Concentration-response curves for $\mathrm{Ca}^{+2}$ were achieved before and after the pre-incubation of the preparation with EBDA $(0.1-1 \mathrm{mg} / \mathrm{ml})$ for 40 minutes. Normal tyrode solution was substituted by tyrode solution containing $80 \mathrm{mM}$ potassium without calcium. At this point, concentrations of calcium varying from low to high $\left(10^{-4} \mathrm{M}-1 \mathrm{M}\right)$ were cumulatively applied.

\section{Solutions and analysis of the information}

The drugs used were methylene blue, diphenydramine, phenylephrine sodium nitroprusside, forskolin, nifedipine, and cromakalin (Sigma Chemical Company, St. Louis, Missouri, USA).

To produce the stock solution, nifedipine was dissolved in absolute ethanol. Forskolin was dissolved in dimetil sulfoxide (DMSO). Thereafter, these, as all the other drugs, were dissolved and diluted in milli-Q water.

Potassium-rich solutions were prepared by substituting the appropriate amount of $\mathrm{KCl}$ for $\mathrm{NaCl} ; \mathrm{Ca}^{+2}$-free solutions were prepared omitting $\mathrm{CaCl}_{2}$.

Results were expressed as relaxation percentage. The relaxation response was defined as: the percentage of reduction of the maximum contraction induced by phenyleprine and $80 \mathrm{mM} \mathrm{K}^{+}$ after the application of EBDA. The greatest relaxation obtained by the largest concentration or its closest value was referred to as maximum relaxation.

The concentration-response curve to $\mathrm{Ca}^{+2}$ was constructed as a percentage of the maximum contraction before and after the addition of different EBDA concentrations.

The results represent the mean \pm standard error values. Differences between the calculated para- meters were evaluated by Student's $t$ test (unpaired) with $\mathrm{p}<0.05$ taken as indicating a significant difference.

\section{RESULTS}

Effects of EBDA, cromakalin, forskolin, nifedipine, and sodium nitroprusside on the maintained contraction evoked by phenylephrine and $80 \mathrm{mM} \mathrm{K}^{+}$

Cromakalin, nifedipine (Fig. 1A) or EBDA (Fig. 1B), unlike the forskolin and sodium nitroprusside that caused a dependent concentration relaxation, failed in relaxing the maintained contraction induced by phenylephrine (Fig. 1A). The maximal EBDA-induced relatation was $8.7 \pm$ $2.2 \%$.

In Table 1 are listed the concentrations of EBDA, cromakalin, forskolin, nifedipine, and sodium nitroprusside required to produce $50 \%$ relaxation in the contraction produced by phenylephrine and high potassium.

Almost complete relaxation was observed with forskolin, sodium nitroprusside (Fig. 2A), and the EBDA (Fig. 2B) in the maintained contraction evoked by high potassium.

Maximal relaxation for EBDA was $94.3 \pm$ $4.7 \%$. Relaxation induced by nifedipine was lower (Table 1). Values are statistically significant $(\mathrm{p}<$ $0.05)$.

Effect of methylene blue on the relaxation produced by $E B D A$ and sodium nitroprusside on the maintained contraction evoked by phenylephrine and $80 \mathrm{mM} \mathrm{K}^{+}$

The methylene blue did not alter the EBDA effect (Fig. 3B) in the contraction induced by the $80 \mathrm{mM}$ potassium, but it did deviate to the right the relaxation induced by the sodium nitroprusside in the maintained contraction induced by phenylephrine and high potassium (Fig. 3A).

\section{Effect of EBDA on the concentration-response curve to the calcium evoked by $80 \mathrm{mM} \mathrm{K^{+ }}$ \\ $\mathrm{Ca}^{+2}$, in the presence of $80 \mathrm{mM} \mathrm{K}^{+}$, induced} a contraction of the anococcygeus muscle in a concentration-dependent manner. The maximum response was reached with $\mathrm{Ca}^{+2}$ in a concentration of $1 \mathrm{M}$ (Fig. 4). 


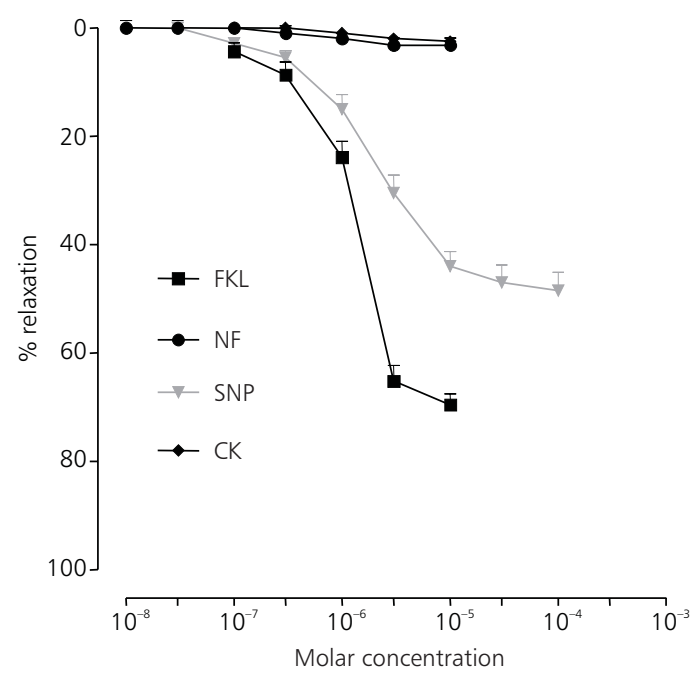

A

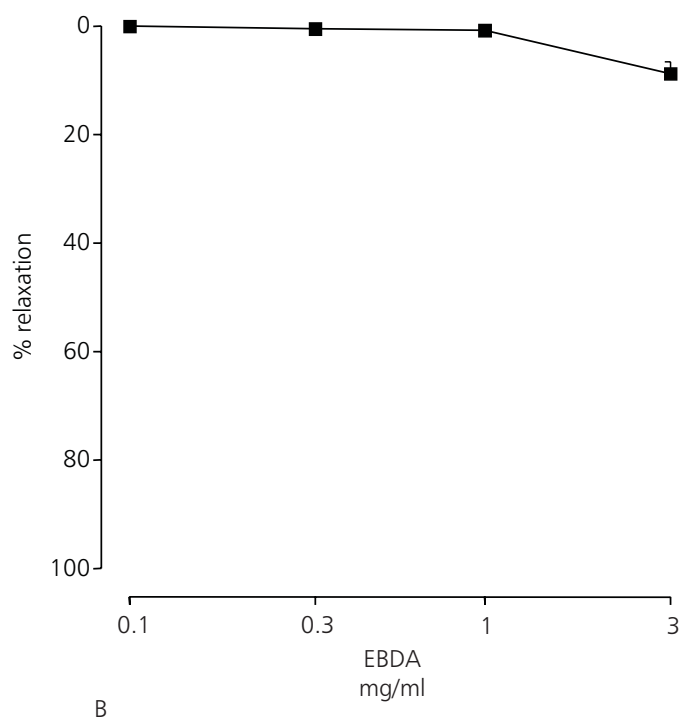

Fig. 1 - (A) Effect of cromakalin (CK), forskolin (FKL), nifedipine (NF), sodium nitroprusside (SNP) and (B) EBDA in the maintained contraction induced by phenylephrine $(10 \mathrm{mM})$. Scale ordinate: $\%$ of relaxation in relation to the maximum contraction induced by potassium. Each point represents the arithmetic average \pm standard error values of 5 experiments. The values are significantly different $(\mathrm{p}<0.05)$ in relation to the control.

TABLE 1

Response to EBDA, cromakalin, forskolin, nifedipine, and sodium nitroprusside in the sustained contraction induced by phenylephrine and potassium in the anococcygeus muscle.

\begin{tabular}{|c|c|c|c|c|}
\hline \multirow{3}{*}{ Agents } & \multicolumn{2}{|l|}{ Phenylephrine } & \multicolumn{2}{|l|}{$80 \mathrm{mM} \mathrm{K}^{+}$} \\
\hline & $\mathrm{IC}_{1 / 2}$ & $\begin{array}{l}\text { Maximum } \\
\text { relaxation }\end{array}$ & $\mathrm{IC}_{1 / 2}$ & $\begin{array}{l}\text { Maximum } \\
\text { relaxation }\end{array}$ \\
\hline & $\mathbf{M}$ & $\%$ & M & $\%$ \\
\hline FKL & $1.1 \times 10^{-6} \mathrm{M}\left(3.8 \times 10^{-7}-3.1 \times 10^{-6}\right)$ & $69.6 \pm 2.1$ & $5.0 \times 10^{-7} \mathrm{M}\left(1.9 \times 10^{-7}-1.3 \times 10^{-6}\right)$ & $94 \pm 6,3$ \\
\hline NF & - & $3.2 \pm 1.4$ & $2.2 \times 10^{-6} \mathrm{M}\left(1.2 \times 10^{-6}-4.0 \times 10^{-6}\right)$ & $73 \pm 2.1$ \\
\hline SNP & $5,0 \times 10^{-7} \mathrm{M}\left(3,6 \times 10^{-7}-0.8 \times 10^{-6}\right)$ & $53.5 \pm 6.2$ & $1.3 \times 10^{-6} \mathrm{M}\left(1.1 \times 10^{-6}-1.7 \times 10^{-6}\right)$ & $90 \pm 2.2$ \\
\hline
\end{tabular}

$\mathrm{IC}_{1 / 2}$ represents the concentration of relaxant agents necessary to produce approximately half of the maximum relaxation. Each value represents the mean values of five experiments. Numbers in parentheses represent $95 \%$ confidence interval.

EBDA reduced the maximum relaxation response of the concentration-effect curve to $\mathrm{Ca}^{+2}$. With EBDA $0.1 \mathrm{mg} / \mathrm{ml}$, the maximum contraction was approximately $89 \pm 8 \%$ in relation to the maximum response of the anoccoccygeus to $\mathrm{Ca}^{+2}$. In the presence of concentrations of 0.3 and $1 \mathrm{mg} / \mathrm{ml}$, the maximum response obtained by $\mathrm{Ca}^{+2}$ was $46.33 \pm$ $8.7 \%$ and $20.33 \pm 5.54 \%(\mathrm{p}<0.05, \mathrm{n}=5)$. 


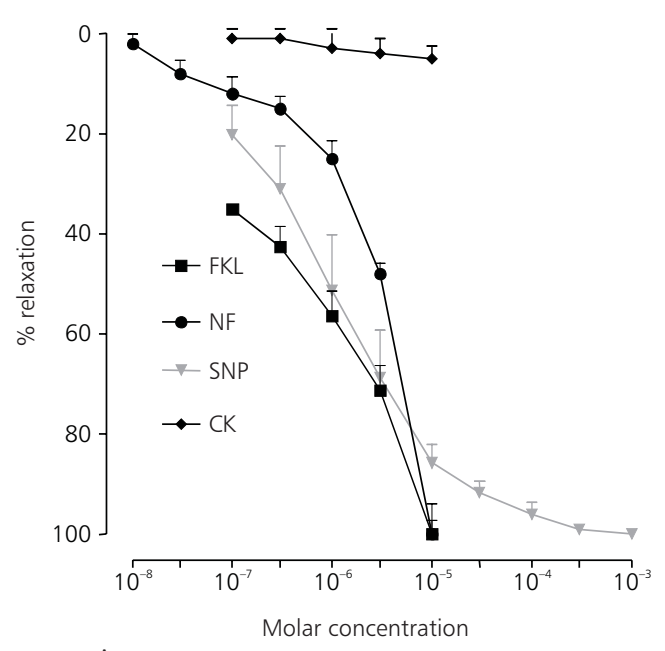

A

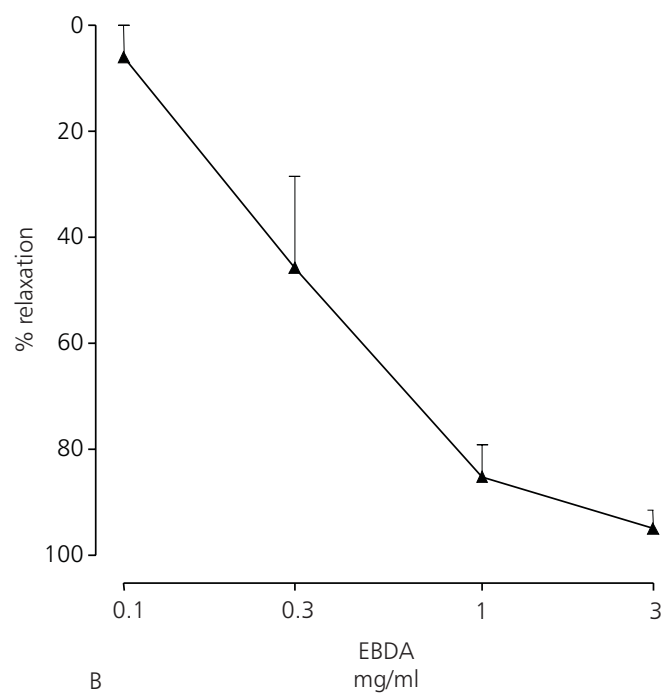

Fig. 2 - (A) Effect of cromakalin (CK), forskolin (FKL), nifedipine (NF), and sodium nitroprusside (SNP) and (B) EBDA in the maintained contraction induced by $80 \mathrm{mM} \mathrm{K}+$. Scale ordinate: $\%$ of relaxation in relation to the maximum contraction induced by potassium. Each point represents the arithmetic average \pm standard error values of 5 experiments. The values are significantly different $(\mathrm{p}<0.05)$ in relation to the control.
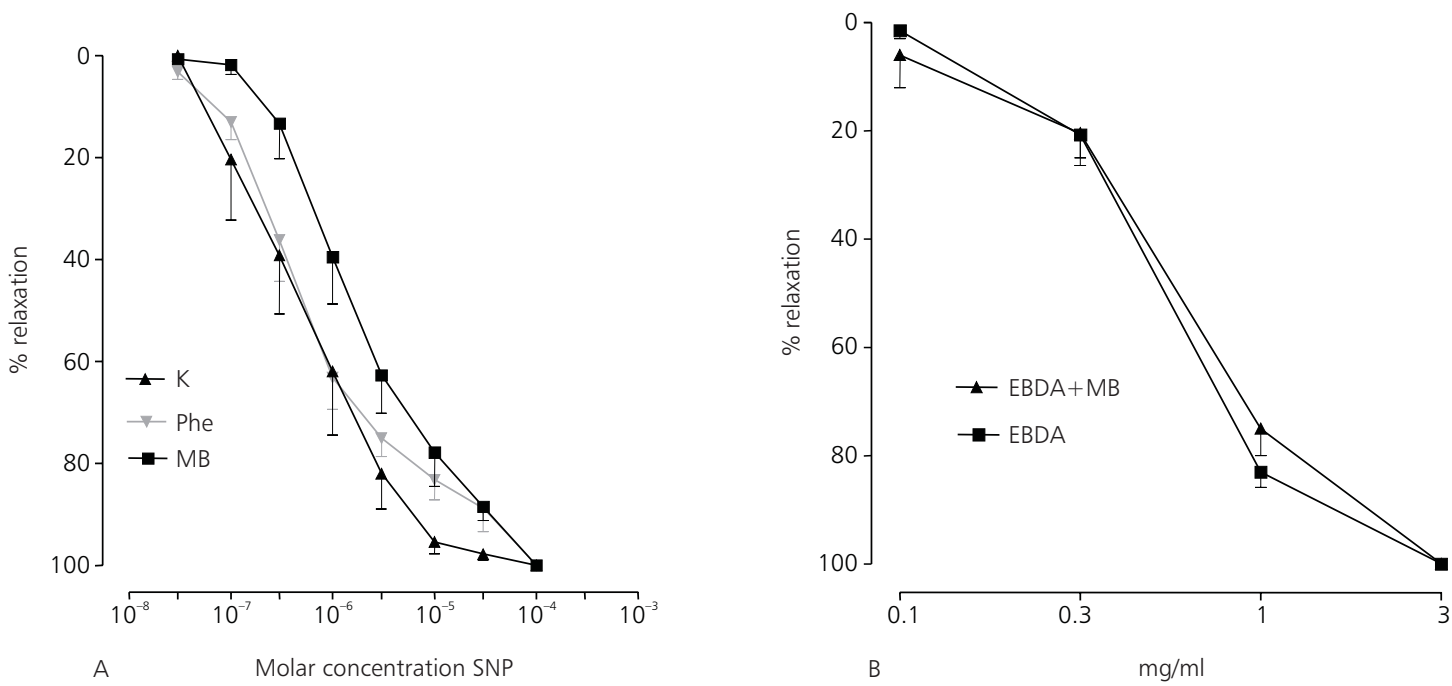

Fig. 3 - (A) Effect of methylene blue (MB) on relaxation induced by sodium nitroprusside (SPN) and (B) EBDA in the maintained contraction induced by $80 \mathrm{mM} \mathrm{K} \mathrm{K}^{+}$and phenylephrine $(10 \mathrm{mM})$. Scale ordinate: \% of relaxation in relation to the maximum contraction induced by potassium. Each point represents the arithmetic average \pm standard error values of 5 experiments. The values are significantly different $(\mathrm{p}<0.05)$ in relation to the control. 


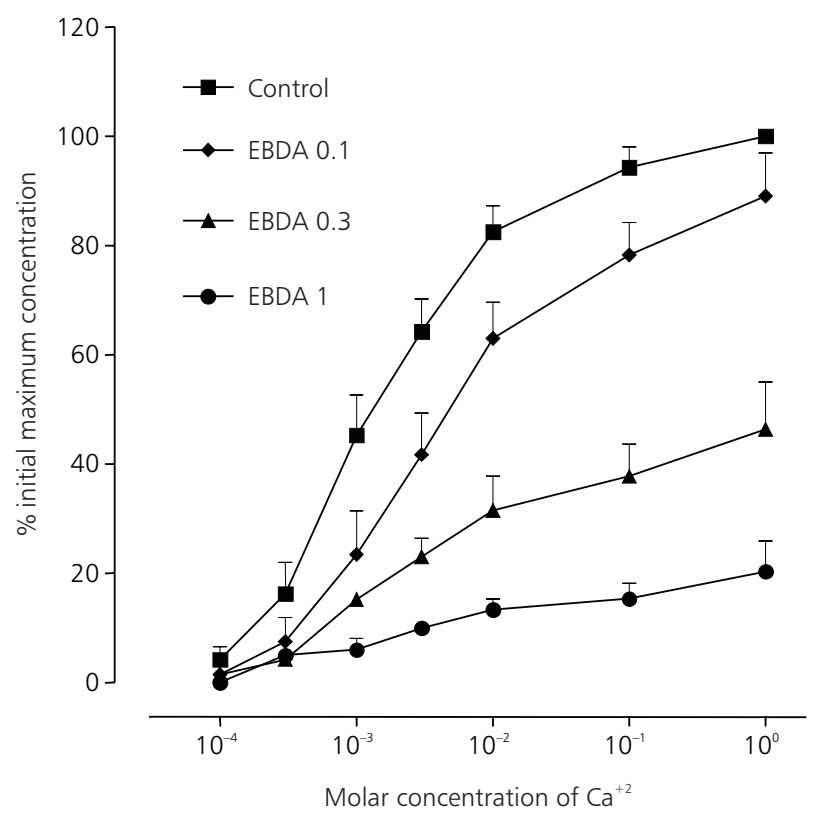

Fig. 4 - Effect of EBDA on the curve concentration-response to $\mathrm{Ca}^{+2}$ in the anococcygeus of rats. Scale ordinate: \% percentage of the maximum contraction induced by calcium. Each point represents the arithmetic average \pm standard error values of 5 experiments. The values are significantly different $(\mathrm{p}<0.05)$ in relation to the control.

\section{DISCUSSION}

Ethanol extracted from the plant Desmodium adscendens found in Cuiabá, is also capable of relaxing smooth muscle since it relaxed completely, and in concentration-dependent manner, the maintained contraction of anococcygeus induced by $80 \mathrm{mM} \mathrm{K}^{+}$(Fig. 2B). Furthermore, in studies of acute toxicity in mice carried out by $\mathrm{N}^{\text {'Gouemo }}$ et al. (1996), no effect of this extract was observed.

This makes real the possibility of offering the local population, particularly those with low incomes, a therapeutic alternative mainly in the treatment of very common disturbances of the respiratory tract, a frequent regional problem during the dry season.

Smooth muscle relaxation can happen through: (a) increase of permeability of the membrane to potassium; (b) mobilization of ions of calcium; (c) increase of the cyclical nucleotideos (GMPc and $\mathrm{AMPc}$ ); (d) direct action on the contractile proteins; and (e) reduction of sensibility to calcium (Cox, 1990).
In relation to the increased permeability of the membrane to potassium, recently Macmanus et al. (1993) characterized three active principles, potent openers of large-conductance calcium-dependent potassium channels $\left(\mathrm{BK}_{\mathrm{Ca}}\right)$ present in the butanolic fraction of the plant. Salsoline, a 6hydroxy tetrahydroisoquinoline derivitive, also seems to be present in the butanolic fraction of the plant (Asante-Poku et al., 1988). The tetrahydroisoquinoline structure of salsoline has been associated with the blockade of calcium-dependent voltage channels (Frank King et al., 1988).

One of the characteristics that distinguishes substances that act by opening potassium channels in substances is little or no alteration in the contractions induced by potassium on the order of 40$80 \mathrm{mM}$ (Hollingsworth et al., 1987).

To verify the possibility of the extract acting in other mechanisms besides the opening of potassium channels, we adopted a simple experimental model: analysis of the EBDA effect on the maintained contraction evoked by a solution containing $80 \mathrm{mM} \mathrm{K}$. 
In this experiment, we observed that EBDA completely relaxed, in a concentration-dependent manner, maintained contractions of the anococcygeus induced by potassium (Fig. 2B).

According to Gibson et al. (1994b), the contractions induced by high potassium concentrations are due to the entrance of $\mathrm{Ca}^{+2}$ mediated through $\mathrm{Ca}^{+2}$-dependent voltage channels, because the responses are eliminated in environments free of $\mathrm{Ca}^{+2}$ or in the presence of the $\mathrm{Ca}^{+2}$ channel blocker, nifedipine.

The EBDA can probably relax the maintained contraction of the induced potassium, through the $\mathrm{Ca}^{+2}$-dependent voltage channel modulation.

To confirm this hypothesis, another experimental procedure analyzed the relationship between the influx of $\mathrm{Ca}^{+2}$ and the contraction it produced. The protocol consisted of pre-incubating the muscle with a solution free of $\mathrm{Ca}^{+2}$, to stimulate it with a high-potassium solution free of $\mathrm{Ca}^{+2}$, and to increase gradually the solution of $\mathrm{Ca}^{+2}$ in the bath.

In the study, EBDA reduced in a concentration-dependent way the maximum response of $\mathrm{Ca}^{+2}$ concentration-effect curve in the anococcygeus (Fig. 4), demonstrating that one of the actions probably involved in the relaxation induced by EBDA is a $\mathrm{Ca}^{+2}$-dependent voltage channel blocker.

$\mathrm{A} \mathrm{Ca}^{+2}$-dependent voltage blocker, such as D 600, verapamil, and nifedipine, does not act on the contraction of the anococcygeus induced by noradrenaline and phenilephrine. This fact has been observed by Villa et al. (1985), Iravani \& Aboo Zar (1993), and Silva et al. (1993).

In the anococcygeus, phenylephrine begins a powerful contraction, which is eliminated in an environment free of $\mathrm{Ca}^{+2}$, but is insensible to nifedipine, suggesting that it is mediated by the entrance of $\mathrm{Ca}^{+2}$ in the cell through nonselective cations current-dependent on the increase of intracelular $\mathrm{Ca}^{+2}$ promoted by $\mathrm{IP}_{3}$ (Gibson et al., 1994b).

The results obtained in this study are in accordance with the results described in the literature, since nifedipine was not able to relax the maintained contraction in the anococcygeeus induced by phenyleprine, in a way similar to EBDA (Figs. 1A and $1 \mathrm{~B}$, respectively). However, both were effective in relaxing in a concentration-dependent way the maintained contraction of the anococcygeus induced by $\mathrm{K}+80 \mathrm{mM}$ (Figs. 2A and 2B). The present data suggests that the relaxing effect of EBDA on this muscle involves another mechanism, probably through a $\mathrm{Ca}^{+2}$-dependent voltage channel blocker.

The debate on the mechanism involved here is open. Its is possible that potassium channels might be involved in the relaxation induced by EBDA since it was isolate substances openers $\mathrm{BK}_{\mathrm{Ca}}$ (MacManus et al., 1993). Further studies are necessary to test this possibility. The exact mechanism by which the extract of Desmodium adscendens produces relaxation of smooth muscle remains to be identified.

In relation to the involvement of EBDA in other stages of muscular contraction, the results obtained until now do not allow us to discard the possibility of its acting on smooth muscle through the reduction of an elevated level of $\mathrm{Ca}^{+2}$ due to the activation of $\mathrm{Ca}^{+2}$-ATPase by the direct action on the contractile proteins, or by reduction of sensitivity to $\mathrm{Ca}^{+2}$.

In relation to AMPc, it has been demonstrated that elevation of its levels is related to relaxation of the anococcygeus (Mirzazadeh et al., 1991; Wendt \& Raymond, 1996). In this study, we can discard the possibility of EBDA, in the concentrations used, acting through the increase of AMPc, since forskolin relaxed the maintained contraction induced by potassium and by phenylephrine (Figs. $1 \mathrm{~A}$ and $2 \mathrm{~A}$ ).

One of the tissues in which the relaxation induced by the nitregic nerve has been broadly studied is the anococcygeus muscle, a smooth nonvascular muscle. In this tissue, the relaxation induced by the nervous stimulation is blocked by the inhibitors of the nitric oxide synthesis (Gibson et al., 1994a, b).

Stimulation of the non-adrenergic non-colinergic nerves (NANC) or the application of exogenous nitrate such as sodium nitroprusside on this tissue, produces a strong relaxation. It is commonly accepted that sodium nitroprusside supports relaxation of the vascular smooth muscle through the liberation of nitric oxide that activates the cytosolic guanylyl cyclase, increasing the levels of GMPc. In this line, Zhang (1993) demonstrated that the sodium nitroprusside was capable of relaxing the trachea of guinea pigs. This effect was reduced by methylene blue, an inhibitor of the guanylate cyclase, and potentiated by zaprinast, inhibitor of the phosphodiesterase.

The results show that relaxation induced by sodium nitroprusside in the contraction of the ano- 
coccygeus induced by phenylephrine and by potassium was diverted to the right by methilene blue, suggesting that, in this case, there might be participation of GMPc in the relaxation induced by phenylephrine (Fig. 3A).

This result suggests further that relaxation of the butanolic fraction is probably not related to increased intracellular concentration of GMPc, considering its inability to relax the contraction of the anococcygeus induced by phenylephrine (Fig. 3B).

In summary, the results obtained demonstrate that EBDA of Desmodium adscendens leaves found in Mato Grosso, is also capable of relaxing smooth non-vascular muscles in the anococcygeus of rats.

Also, they provide indirect evidence that, at least in part, the effect of the extract is probably related to the blocking of $\mathrm{Ca}^{+2}$ dependent voltage channels.

\section{REFERENCES}

ADDY, M. E., 1989, Several chromatographically distinct fractions of Desmodium adscendens inhibit smooth muscle contractions. Int. J. Crude Drug Res., 27(2): 81-91.

ADDY, M. E. \& BURKA, J. F., 1988, Effects of Desmodium adscendens fractions on antigen-and arachidonic acidinduced contractions of guinea pig airways. Can. J. Physiol. and Pharmacol., 66: 20-825.

ADDY, M. E. \& SCHARTZMAN, M. L., 1992, An extract of Desmodium adscendens inhibits NADPH-dependent oxygenation of arachidonic acid Kidney cortical microsomes. Phytother. Rres., 6: 245-250.

ADDY, M. E. \& AWUMEY, E. M. K., 1984, Effects of the extracts of Desmodium adscendens on anaphylaxis. J. Ethnopharmacol., 11: 183-192.

AMPOFO, O., 1977, Plants that heal. World Health, 26: 2834.

ASANTE-POKU, S., SASAKIBARA, J. \& ADDY, M. E., 1988, Alkaloids of Desmodium adscendens. Ghana Med. J., 22: 111-115.

COX, R. H., 1990, $\mathrm{K}^{+}$-channel activators in vascular smooth muscle. In: T. J. Colatsky (ed.), Potassium channel: basic function and therapeutic aspects. Wiley-liss, New York, pp. 279-301.

FRANK KING, V., GARCIA, M. L., HIMMEL, D., REUBEN, J. P. \& KACZOROWSKI, G. J., 1988, Interaction of tetrandine with slowly inactivating Calcium Channels. $J$. Biol. Chem., 263(5): 2238-2244.

GIBSON, A., BRAVE, S. R., MCFADZEAN, I., MIRZAZADEH, S., TUCKER, J. F. \& WAYMAN, C. P., 1994a, Nitergic stimulation does not inhibit carbachol-induced inositol phosphate generation in the rat anococcygeus. Neuroscience Lett., 178: 35-38.
GIBSON, A., MCFADZEAN, I., TUCKER, J. F. \& WAYMAN, C. P., 1994b, Variable potency of nitrergic-nitrovasodilator relaxations of the mouse anoccoccygeus against different forms of induced tone. Br. J. Pharmacol., 113: 1494-1500.

GUARIN NETO, G., 1996, Plantas medicinais do Estado do Mato Grosso. Associação Brasileira de Educação Agrícola Superior, p. 31.

HOLLINGSWORTH, M., AMÉdÉE, T., EDWARDS, D., MIRONNEAU, J., SAVINEAU, J. P., SMALL, O. \& WESTON, A. H., 1987, The relaxant action of BRL 34915 in rat uterus. Br. J. Pharmacol., 91: 803-813.

IRAVANI, M. M. \& ABOO ZAR, M., 1993, Differential effects of nifedipine on nerve-mediated and noradrenalineevoked contractions of rat anococcygeus muscle. Eur. J. Pharmacol., 250: 193-195.

MACMANUS, O. B., HARRIS, G. H., GIANGIACOMO, K. M., FEIGEBAUM, J. P., REUBEM, J. P., ADDY, M. E., BURKA, J. F., KACZOROWSKI, G. J. \& GARCIA, M. L., 1993, An activator of calcium-dependent potassium channel isolated from a medicinal herb. Biochem. J., 32: 6128-6133.

MIRZAZADEH, S., HOBBS, A. J., TUCKER, J. F. \& GIBSON, A., 1991, Cyclic nucleotide content of the rat anococcygeus during relaxations induced by drugs or by non-adrenergic, non-colinergic field stimulation. J. Pharm. Pharmacol., 43: 247-257.

N'GOUEMO, P., BALDY-MOULINIER, C. \& NGUEMBYBINA, C., 1996, Effects of an ethanolic extract of Desmodium adscendens on central nervous system in rodents. J. Ethnopharmacol., 52: 77-83.

PIO CORRÊA, M., 1984, Dicionário das plantas úteis do Brasil e das exóticas cultivadas. Imprensa Nacional, Rio de Janeiro, pp. 1931-1978.

SILVA, C. R., SCANNAVINO, A. F., REIS Jr., D. S., OLIVEIRA, A. M. \& BENDHACK, L. M., 1993, Estoques intracelulares de $\mathrm{Ca}^{+2}$ em músculo anococcígeo de ratos. In: II Jornada de Pesquisa e Pós-graduação em Farmacologia, Resumos, Ribeirão Preto, p. 467.

VILLA, E., THOOLEN, M. J. M. C., BECKERINGH, J. J., TIMMERMANS, P. B. M. W. M. \& VAN ZWIETEN, P. A., 1985, Lack of D600 on a1-adrenoceptor-mediated contractions of rat isolated anococcygeus muscle. Eur. J. Pharmacol., 106: 97-105.

WENDT, I. R. \& RAYMOND, G. L., 1996, Force and intracellular $\mathrm{Ca}^{2+}$ during cyclic nucleotide-mediated relaxation of rat anococcygeus muscle and the effects of cyclopiazonic. Br. J. Pharmacol., 119: 1029-1037.

ZHANG, Y., PALETTE-PAYS, C., NALINE, E., VAROQUAUX, O. \& ADVENIER, C., 1993, Effects of molsidomine and linsidomine on the human isolated bronchus and in the guinea pig isolated trachea. J. Pharm. Pharmacol., 45: 280-285. 